\title{
FROM FAMILIAR TO UNCANNY. \\ THE AESTHETICS OF ATMOSPHERES \\ IN DOMESTIC SPACES
}

\section{A B S T R A C T}

The notion of "familiar" has recently become crucial in the debate generated by Everyday Aesthetics. In this essay, I will explore this concept in the theories of Arto Haapala and Yuriko Saito, then I will examine the notion of familiar - and some antonym notions (i.e. strange, uncanny, alien) - while embracing a phenomenological approach. Referring to German phenomenologist Gernot Böhme's theory of atmospheres, my paper compares the notion of a glass house, theorised by Modernism, and the notion of a shell house, seen from different perspectives by Walter Benjamin, Gaston Bachelard and Juhani Pallasmaa. I will finally draw a parallel with the notion of strange possibly degenerating into the idea of uncanny or alien, for instance when the transparency of glass is used as a tool for control or when it is embodied in the digital screens of hypertechnological homes.

Elisabetta Di Stefano 


\section{INTRODUCTION}

The notion of "familiar" has recently become crucial in the debate generated by Everyday Aesthetics, a theoretical trend set up against the mainstream of AngloAmerican Aesthetics, and focusing on the philosophy of art. Starting with Arto Haapala's essay ${ }^{1}$ and consolidating with Yuriko Saito's book, Aesthetics of the familiar, $^{2}$ the notion of familiar has been used to put emphasis on the value of everyday life, often disregarded because of its normality. In our life, everyday space and objects often form a kind of background which intrigues us only when something strange happens, however the value of what is familiar should not be underestimated, inasmuch as it makes us feel comfortable and "at home".

In this essay I will investigate the notion of familiar - and some antonym notions (i.e. strange, uncanny, alien) - while embracing a phenomenological approach that is unaccounted for within the American debate and only partially acknowledged by Haapala's essay. Referring to German phenomenologist Gernot Böhme's theory of atmospheres, I will review two models of inhabiting, symbolically conveyed one by the shell house and the other by the glass house. In the popular imagination, the former is linked to the idea of familiar as far as it stands for protection, privacy, warmth; while the latter is linked to the idea of strange due to a feeling of coldness and impersonal.

The notions of familiar and strange clearly hint to two different domestic atmospheres and two distinct sensory paradigms: the one of touch and that of sight. The glass house, however, is also the emblem of the modernist style, to which we owe masterpieces of great aesthetic impact. The notion of strange in this case hints to something special, out of the ordinary, like a work of art.

I will finally draw a parallel with the notion of strange possibly degenerating into the idea of uncanny or alien, for instance when the transparency of glass is used as a tool for control or when it is embodied in the digital screens of hypertechnological homes.

\section{TWO MODELS OF INHABITING: SHELL HOUSE AND GLASS HOUSE}

The complex set of meanings detected in the idea and in the lived experience of a home is a relatively recent finding in Western culture. Revolving around the polarisation of public and private, internal and external, it is the consequence of the changes in bourgeois society launched by the increasing urbanism of the eighteenth century and consolidated during the nineteenth century. In the modern popular imagination, a home is a place of intimacy and affections; it is the kingdom of what is familiar to us. 
I will take into account two approaches to the understanding and living of a home: the shell house and the glass house. According to Walter Benjamin, the first is the original model of inhabiting, clearly represented by the nineteenth century homes, where the occupant was protected like a compass in its case. By contrast, the second is the expression of modernist style, which relies on glass and steel in order to achieve inhabiting models that are more for contemplation than for living.

The original form of all dwelling is existence not in the house but in the shell. The shell bears the impression of its occupant. In the most extreme instance, the dwelling becomes a shell. The nineteenth century, like no other century, was addicted to dwelling. It conceived the residence as a receptacle for the person, and it encased him with all his appurtenances so deeply in the dwelling's interior that one might be reminded of the inside of a compass case, where the instrument with all its accessories lies embedded in deep, usually violet folds of velvet. ${ }^{3}$

The shell house, as Benjamin describes it, focuses on two features pertaining to the idea of intimacy: protection and privacy. In the nineteenth century dwellings, velvet curtains are there not only to fend off sunlight, thus creating a shaded atmosphere, but also to hide the inside from prying eyes. Privacy is the main feature of the nineteenth century dwellings. Their closets, dressers, chests of drawers, secretaires are the many "cases" in which one can hide one's dearest and most secret possessions. It is not a coincidence that Benjamin makes use of detective-like metaphors as he tries to convey this peculiar feature of the eighteenth-century dwellings, where every object, piece of furniture, ornament becomes a "trace" and a "footprint" of the identity of the inhabitants:

To dwell means to leave traces. In the interior, these are accentuated. Coverlets and antimacassars, cases and containers are devised in abundance; in these, the traces of the most ordinary objects of use are imprinted. In just the same way, the traces of the inhabitant are imprinted in the interior. Enter the detective story, which pursues these traces. ${ }^{4}$

On the contrary, with its algid beauty, glass seems to reject everything (i.e. furniture or decor) that could downplay its prominence. In this regard, one of the first theoreticians of the Glasarkitektur, Paul Scheerbart, claims that: 'It will surely appear self-evident that the furniture in the glass house may not be placed against the precious, ornamentally-coloured glass walls. Pictures on the walls are, of course, totally impossible'.5 
This minimalist aesthetics deprives the occupant of the glass house of the pleasure to possess objects. This is why, according to Benjamin, since in the glass house "it is hard to leave traces", ${ }^{6}$ it is more difficult to establish an emotional relation with things.

Besides being the "enemy of possession", glass is also the "enemy of secrets"? Therefore, the transparency Breton and Scheerbart take as ethical virtue ('our hope is that glass architecture will also improve mankind in ethical respects' ${ }^{8}$ ) is for Benjamin the sign of "moral exhibitionism" inasmuch as it entails the disappearance of "Discretion concerning one's own existence". ${ }^{10}$ Thanks to glass architecture the gaze of those who are inside is no longer filtered by the window, but can turn in every direction in the seeming continuity between inside and outside. ${ }^{11}$ However, also those who are outside can indulge in voyeuristic pleasure since, once walls disappear, no barrier stands in between the prying eye and the most intimate domestic areas.

The glass house is linked to an aesthetics of visibility and seems to embody the expositional values that belong to a work of art. For this reason, one of the supporters of Everyday Aesthetics, Kevin Melchionne, has emphasised the limits of one's daily life lived inside the glass house: 'At first glance, the Glass House seems to be very much a work of environmental art. Surrounded by glass walls, the occupant is immersed in, though not physically subject to, the shifting atmospheric conditions of the outdoor'. ${ }^{12}$ At the same time, 'The glass walls render the occupant perpetually self-conscious of being watched' ${ }^{13}$ As a consequence, the occupants will never be able to behave in a relaxed way, like actors on stage, they will always be prey of other people's gazes. They won't be able to leave dirty laundry on the floor or out of place, nor dirty dishes in full sight; like art curators they will rather have to comply with rules not to destroy the aesthetics of the composition.

It is clear that glass and steel modernist architecture has often favoured style over comfort, thus producing houses of great aesthetic impact, but of little usability. This is why the occupant of the glass house reminds us of Adolf Loos' "poor little rich man" who lives in a house, designed and furnished by a famous architect, where he cannot move the furniture from its assigned position or add new objects, since that would jeopardise the artistic perfection of the work of art. 
Each appliance had its own definite place. The architect had done his best for him. He had thought of everything in advance. There was a definite place for even the very smallest case, made just especially for it. The domicile was comfortable, but it was hard mental work. In the first weeks the architect guarded the daily life, so that no mistake could creep in. The rich man put tremendous effort into it. But it still happened, that when he laid down a book without thinking that he stored it into the pigeonhole for the newspaper. Or he knocked the ashes from his cigar into the groove made for the candleholder. You picked something up and the endless guessing and searching for the right place to return it to began, and sometimes the architect had to look at the blueprint to rediscover the correct place for a box of matches. ${ }^{14}$

In Loos' story the house finally becomes unfamiliar: out of the ordinary and beautiful to look at, but unable to make its inhabitant happy. The poor little rich man, in fact, 'tried to be home as little as possible' because 'now and then one needs a break from so much art'. ${ }^{15}$

Although the glass house seems to embody the aesthetic values of a work of art meant to be contemplated, one could not say that the shell house has less artistic value. Benjamin himself claims that the interiéur of the eighteenth-century homes, with all its objects, is not only the most intimate part of the house but also "the asylum where art takes refuge".

In the interior, he brings together remote locales and memories of the past. His living room is a box in the theater of the world. The interior is the asylum where art takes refuge. The collector proves to be the true resident of the interior. He makes his concern the idealisation of objects. To him falls the Sisyphean task of divesting things of their commodity character by taking possession of them. But he can bestow on them only connoisseur value, rather than use value. The collector delights in evoking a world that is not just distant and long gone but also better - a world in which, to be sure, human beings are no better provided with what they need than in the real world, but in which things are freed from the drudgery of being useful. ${ }^{16}$

The difference between the shell house and the glass house does not lie in their artistic value, but rather in the fact that they exude a different atmosphere, in other words a different relation between the space and the perceiving subject. Regardless of how humble or luxurious, how cold or cosy the home is, the feeling 
of inhabiting lies in the emotional relation established with the objects, the same objects which contribute to create the identity of the inhabitant. Nevertheless, although with more limits, the glass house can reflect the personality of its occupants. For instance, in the novel Nadja (1928), Breton describes his glass house - a metaphor for his internal I - as a house with a surreal atmosphere, where the physical property of glass becomes the sign of moral transparency.

I myself shall continue living in my glass house where you can always see who comes to call; where everything hanging from the ceiling and on the wall stays where it is as if by magic, where I sleep nights in a glass bed, under glass sheets, where who I am will sooner or later appear etched by a diamond. ${ }^{17}$

Based on this, Mario Praz ${ }^{18}$ claims that "the house is the person" and one's approach to furnishing tells us more about one's character and one's idea of beauty than the clothes they wear. Bringing this idea to the extreme, in the novel Dead Souls (1842) by Nicolaj V. Gogol, the furniture in the house of the landowner Sobakevič not only mirrors his personality, but also his physical appearance:

Meanwhile Chichikov again surveyed the room, and saw that everything in it was massive and clumsy in the highest degree; as also that everything was curiously in keeping with the master of the house. For example, in one corner of the apartment there stood a hazelwood bureau with a bulging body on four grotesque legs - the perfect image of a bear. Also, the tables and the chairs were of the same ponderous, unrestful order, and every single article in the room appeared to be saying either, "I, too, am a Sobakevitch," or "I am exactly like Sobakevitch". ${ }^{19}$

\section{THE AESTHETICS OF ATMOSPHERES}

The German philosopher Böhme placed the notion of atmosphere in the centre of a "new" phenomenological theory of aesthetics. According to Böhme, the atmosphere is the result of a synaesthetic perception - therefore not only visual, but also tactile, olfactory and motor - of a "space attuned" (gestimmter Raum) to a mood.

Environments can pick up or oppress people, just like shapes and colours can influence us. They can be homely or unhomely, cold or welcoming, sober or cheerful, and they convey a spurning or attractive atmosphere. However, Böhme has pointed out, things and their properties (i.e. shape, colour, etc.) are not the primary content of sensing, but rather the relation among things themselves and to the perceiving subject. 
In the shell house, going back to the two models here, the atmosphere of intimacy is produced by opaque and warm materials (e.g. wood and bricks), by colourful wallpaper, soft velvet sofas and thick curtains. The atmosphere of intimacy is always shaded. It can be lit up by lamps or candles, as suggested by the philosopher Gaston Bachelard, ${ }^{20}$ or warmed up by a flame in a fireplace, as claimed by the Finnish architect Pallasmaa. The latter is the supporter of an idea of architecture which in the articulation of space is able to convey an intense feeling, almost of religious meditation, where the fireplace becomes the symbol of intimacy and comfort: 'The experience of the home is essentially an experience of intimate warmth. The space of warmth around a fireplace is the space of ultimate intimacy and comfort'. ${ }^{21}$

This warm and welcoming atmosphere evokes the idea of the maternal womb, our first home, where we could curl up and feel protected. Furthermore, while talking about the shell house and nest house, Bachelard points out to the value of the action of "curling up" as expressing the original and most intense meaning of inhabiting: 'In our houses we have nooks and corners in which we like to curl up comfortably. To curl up belongs to the phenomenology of the verb to inhabit, and only those who have learned to do so can inhabit with intensity. ${ }^{22}$

The relation between the position of the curled up body and the shape of the shell house wrapping the body in soft fabric recalls one more symbolic image of the first inhabiting, that is to say the crib. It is again Bachelard who reminds us that, as a newborn baby, 'man is laid in the cradle of the house. And always in our daydreams, the house is a large cradle'. ${ }^{23}$

The model of inhabiting conveyed by the symbols of the shell, the nest, and the cradle can be linked to the notion of familiar with reference to the sensory realm of touch (the softness of fabrics; the warmth of the fireplace or candles; the meditative curled up position of the body). On the contrary, the model of inhabiting conveyed by the glass house recalls, as previously mentioned, the sensory realm of the eye and expositional values of a work of art to be contemplated from a distance. In this way the latter model of inhabiting can be linked to the notion of strange, in the sense of both extraneous and extraordinary. By clarifying that the two models rely on distinct sensory realms, Pallasmaa adds that visibility has to do with investigation, rationality, and distance, while touch has to do with proximity and imagination; the most intense aesthetic experiences are in fact those enjoyed with closed eyes:

The eye is the organ of distance and separation, whereas touch is the sense of nearness, intimacy and affection. The eye surveys, controls and investigates, whereas touch approaches and caresses. During 
overpowering emotional experiences, we tend to close off the distancing sense of vision; we close the eyes when dreaming, listening to music, or caressing our beloved ones. Deep shadows and darkness are essential, because they dim the sharpness of vision, make depth and distance ambiguous, and invite unconscious peripheral vision and tactile fantasy. [...] The imagination and daydreaming are stimulated by dim light and shadow. ${ }^{24}$

\section{STRANGE, UNCANNY, ALIEN}

Granted that a home expresses the identity of those who inhabit it, whenever it is haunted by an extraneous entity (for instance a ghost) or whenever, technologically self-governed, seems to have a life of its own, it loses its familiar connotations and becomes strange, uncanny, or even alien.

Nineteenth century literature offers multiple examples of houses which, behind a welcoming and familiar appearance, hide a dark side. Here one could make reference to E. T. A. Hoffman or Edgar Allan Poe's grotesque stories, as well as to those by the French authors Charles Nodier and Victor Hugo, which feature abandoned houses, surrounded by superstitions or haunted by ghosts.

As Anthony Vidler has remarked, the uncanny in architecture is not a property of space, nor is it evoked by a given conformation, but it rather ensues from the aesthetic dimension; no single building nor design trick will be able to mathematically provoke an uncanny feeling. However, Vidler also recognises that 'the buildings and spaces that have acted as the sites for uncanny experiences have been invested with recognisable characteristics' ${ }^{25}$ In order to explain this disquieting feeling which cannot be traced back to rational elements, one can rely on the aesthetics of atmosphere and the emotional relation established between the environment and the perceiving subject.

A paradigmatic example is provided by Poe's story, The Fall of the House of Usher (1839). The house is described as melancholic and already at first sight it evokes 'a sense of insufferable gloom'. The uncanny feeling is not only the result of the conformation of the house with "vacant eye-like" windows, but it also comes from the surrounding atmospheric space, in other words the gloomy landscape, the solitude of the main character, the autumnal season: 'During the whole of a dull, dark, and soundless day in the autumn of the year, when the clouds hung oppressively low in the heavens, I had been passing alone, on horseback, through a singularly dreary tract of country. ${ }^{27}$ 
Also the glass house can become uncanny and even alien, as shown by literary and cinematographic science fiction. In this regard one can recall the novel We written between 1919 and 1921 by the Russian novelist Evgenij Ivanovič Zamjatin, who is considered the forefather of the negative-utopia or dystopia genre. The novel focuses on the totalitarianism and conformism of the Soviet regime at the beginning of the twentieth century, but its setting is in the future, where homes are only built in glass so that everybody can be seen and controlled at any given moment. Also the film director Sergej M. Ejzenštejn, in his unfinished film project titled Glass House (1926-30), saw the disquieting shadow of a future made of oppressive transparency in glass architecture. The hypertechnological home follows the same line. Here walls disappear like thin digital membranes in constant mutation. By means of a sensor network these interactive walls react to stimuli (i.e. sounds, lights, and smells), thus creating unusual communication flows between the inside and outside..$^{28} \mathrm{~A}$ good example is provided by the unsettling project signed by two architects from New York, Elisabeth Diller and Ricardo Scofidio. Based on their design an external camera selects the shots, records the landscape, and then projects it onto virtual windows, thus giving a new interpretation to the theories of Surrealism on the mechanical body in the light of cybernetic culture.

The hypertechnological house can therefore appear comfortable and functional at first sight, but it can also become alien, if not hostile, possibly transforming itself into a self-governing prison, as it is for the Glass family in Daniel Sackheim's film with the suggestive title The Glass House (2001).

\section{CONCLUSION}

The notions of familiar and strange, although they are antonyms, might bland one into the other. A familiar and ordinary space can be made out of the ordinary, as it is when a home is transformed into a work of art. Such an intervention may well run the risk of making a home uncomfortable and unfamiliar. Furthermore, such a de-familiarisation can lead to uncanny results, as shown by literary examples of ghost haunted houses or glass houses. Finally, it can produce alienating effects in hypertechnological homes which seem to have a life of their own. The notion of home is indeed complex and connected to the feeling of inhabiting, that is to say to the relation established between the perceiving subject and the atmospheric space. It is nevertheless possible to launch a domestication process in order to make the spaces that are perceived as extraneous familiar or in order to create a welcoming atmosphere in those 
places that seem cold and impersonal. According to Böhme, atmospheres do not exist as physical objects, but they are identifiable and therefore can be produced through some given natural elements (e.g. water, flowers, trees, etc.) or artificial elements (e.g. light, sound, architectural features).

The aesthetics of atmospheres is therefore a useful theoretical tool not only in literary descriptions and in theatrical and cinematographic settings, but also in daily life, where it can provide theoretical and practical support in the production of synthonic relations between the subject and the surrounding space. It can thus be helpful when it comes to social and individual alienation or the issues connected to integration, contributing to atmospheres that qualify as inclusive and suitable to express the identity of single individuals as well as communities.

Arto Haapala, "On the Aesthetics of Everyday: Familiarity, Strangeness and Meaning of Place," in The Aesthetics of Everyday Life, eds. Andrew Light and Jonathan M. Smith (New York: Columbia University Press, 2005), 39-55, 50.

Yuriko Saito, Aesthetics of the Familiar. Everyday Life and World-Making (Oxford: Oxford University Press, 2017), 11-23.

Walter Benjamin, The Interior, The Trace, in Arcades Project, transl. by Howard Eiland and Kevin McLaughlin (Cambridge, Mass.- London: The Belknap Press of Harvard University Press, 2002), 220 .

Walter Benjamin, "Paris, the Capital of the Nineteenth Century 'Expose of 1935'," in Arcades Project, 9. 
Scheerbart, Glass Architecture, 63.

Walter Benjamin, Surrealism: the Last Snapshot of the European Intelligentsia (1929), in Selected Writings, vol 2, 1927-1934, 49.

Walter Benjamin, Surrealism, 49.

The idea of a seeming continuity between outside and inside, meant to create the illusion of a full immersion in nature, is the fundamental inspiration, although in different ways, for two renown icons of Modernism in the '50s: the Farnsworth House, (1949-1951) by Ludwig Mies van der Rohe and the Glass House (1949) by Philip Johnson.

Kevin Melchionne, "Living in Glass Houses: Domesticity, Interior Decoration, and Environmental Aesthetics," The Journal of Aesthetics and Art Criticism, vol. 56, n. 2 (1998): 191-200, 191.

Melchionne, Living in Glass Houses, 191.

Adolf Loos, "The Poor Little Rich Men," in Adolf Loos 1870-1933. Architect, Cultural critic, Dandy, ed. August Sarnitz (Hong Kong, Köln, London, Los Angeles, Madrid, Paris, Tokio: Taschen, 2016), 19.

Loos, The Poor Little Rich Men, 19.

Benjamin, Paris. Capital of the Nineteenth Century Expose 'of 1939', Louis Philippe, or the Interior, in Arcades Project, 19.

André Breton, Nadja (1928), transl. by Richard Howard (New York: Grove Press, 1960), 18. Italic in the texts.

Mario Praz, An Illustrated History of Interior Decoration from Pompeii to Art Nouveau (London: Thames and Hudson, 1964).

Nikolai Vasilievich Gogol, Dead Souls, transl. by D. J. Hogarth, 1842. Available at: https://www. gutenberg.org/files/1081/1081-h/1081-h.htm.

Gaston Bachelard, The Flame of a Candle (1961), transl. by Joni Caldwell (Dallas: The Dallas Institute of Humanities and Culture, 1988).

Juhani Pallasmaa, The Eyes of the Skin. Architecture and the Senses (Chichester: John Wiley \& Sons, 2005), 58 .

Gaston Bachelard, The Poetics of Space (1958), transl. by Maria Jolas (Boston, Mass: Beacon Press, 1994), XXXVIII.

Bachelard, The Poetics of Space, 7.

Pallasmaa, The Eyes of the Skin, 46.

Anthony Vidler, The Architectural Uncanny. Essay in the Modern Unhomely (Cambridge, Mass.London: Massachusetts Institute of Technology, 1992), 11.

Edgar Allan Poe, "The Fall of the House of Usher, " in The Complete Tales and Poems (New York: The Modern Library, 1938), 231.

Poe, The Fall of the House of Usher, 231.

Luigi Prestinenza Puglisi, Hyper Architecture: Space in the electronic age, transl. by Lucinda Byatt, (Basel: Birkhäuser Verlag, 1999). 
Bachelard, Gaston. The Flame of a Candle (1961), transl. by Joni Caldwell. Dallas: The Dallas Institute of Humanities and Culture, 1988.

Bachelard, Gaston. The Poetics of Space (1958), transl. by Maria Jolas. Boston, Mass: Beacon Press, 1994.

Benjamin, Walter. The Interior, The Trace, in Arcades Project. Translated by Howard Eiland and Kevin McLaughlin. Cambridge, Mass.- London: The Belknap Press of Harvard University Press, 2002.

Benjamin, Walter. “Experience and poverty.” In Benjamin, Selected Writings. Vol. 2, 1927-1934, transl. by Rodney Livingstone and Others, eds. Michael Jennings, Howard Eiland and Gary Smith. Cambridge, Mass. and London: The Belknap Press of Harvard University Press, 1999.

Breton, André. Nadja (1928), transl. by Richard Howard. New York: Grove Press, 1960.

Haapala, Arto. "On the Aesthetics of Everyday: Familiarity, Strangeness and Meaning of Place." In The Aesthetics of Everyday Life, Edited by Andrew Light and Jonathan M. Smith, 39-55. New York: Columbia University Press, 2005.

Loos, Adolf. "The Poor Little Rich Men.” In Adolf Loos 1870-1933. Architect, Cultural critic, Dandy, ed. August Sarnitz. Hong Kong, Köln, London, Los Angeles, Madrid, Paris, Tokio: Taschen, 2016.

Melchionne, Kevin. "Living in Glass Houses: Domesticity, Interior Decoration, and Environmental Aesthetics." The Journal of Aesthetics and Art Criticism, vol. 56, n. 2 (1998): 191-200, 191.

Pallasmaa, Juhani. The Eyes of the Skin. Architecture and the Senses. Chichester: John Wiley \& Sons, 2005 .

Poe, Edgar Allan. "The Fall of the House of Usher." In The Complete Tales and Poems. New York: The Modern Library, 1938.

Praz, Mario. An Illustrated History of Interior Decoration from Pompeii to Art Nouveau. London: Thames and Hudson, 1964.

Puglisi, Luigi Prestinenza. Hyper Architecture: Space in the electronic age, transl. by Lucinda Byatt. Basel: Birkhäuser Verlag, 1999.

Saito, Yuriko. Aesthetics of the Familiar. Everyday Life and World-Making. Oxford: Oxford University Press, 2017.

Scheerbart, Paul. Glass Architecture (1914). Edited by Dennis Sharp, translated by Shirley Palmer and James C. Palmes. Westport, Connecticut, USA: Praeger, 1972.

Vidler, Anthony. The Architectural Uncanny. Essay in the Modern Unhomely. Cambridge, Mass.London: Massachusetts Institute of Technology, 1992. 
STEREOTIP LEPOTE I IZGRADNJE. ESTETIKA ARHITEKTURE.

\section{Raffaele Milani}

U ovom radu smo se bavili stereotipom kao otpornim modelom tipova stvorenih objekata, slikom proizvodnog procesa koja se ponavlja ili se može ponavljati i standardizovanim modelom virtuelnosti; drugim rečima, stereotipizacija daje formu stvarima unutar sistema objekata koji se serijski reprodukuju. Viševekovna sinteza zanatstva i materijala se u našem vremenu transformisala u dizajn. Rekonstrukcija objekta podrazumeva praćenje tehnika koje su korišćene u nastanku istog, uključujući i one tradicionalne. U pogledu odnosa medju tehnologijama, vodi se žestoka rasprava izmedju onih koji žele da brane tragove prošlosti kao sećanje koje je značajno za budućnost, kao i instrument za harmonizaciju masa, i onih koji u potpunosti favorizuju novitete hibridnog stila koji je u modi posle faze modernizma. Ovi drugi podržavaju deregulaciju proizvodnje arhitektonskih objekata i nekoherentnu, improvizovanu organizaciju prigradskog okruženja. Tokom istorije su postojale značajne razlike u mišljenju o vrednosti čovečanstva, kvalitetu života, načinima razmišljanja i oblicima kulture i umetnosti.

KLJUČNE REČI: ESTETIKA, ARHITEKTURA, UMETNOST, JEZIK, STEREOTIP, ETIKA, LEPOTA

\section{MULTIKRITERIJUMSKA PROCENA LEPOTE U ARHITEKTURI \\ Boguslaw Szuba}

Članak se bavi problemima lepote u arhitekturi koji se nalaze u raznim slojevima značenja koji se odnose na: $\left(^{*}\right)$ kreativnu ideju planirane investicije; $(*)$ sposobnost da se odredi pravo mesto za planiranu investiciju, uskladjujući arhitekturu u prostoru lokacije, sa posebnim osvrtom na prirodno okruženje; $(*)$ komunikaciju i informacije sa okolinom; $(*)$ poštovanje tradicije i običaja koji se poštuju u lokalnom socijalno-kulturnom okruženju, obraćajući pažnju na istorijski kontinuitet i koherenciju arhitektonskih oblika koji se koriste; $\left(^{*}\right)$ kreativnost oblikovanja prostora; (*) preciznost i inovativnost funkcionalnih i korišćenih prostornih rešenja; $\left(^{*}\right)$ partnerski odnos sa susedstvom; $\left(^{*}\right)$ široko shvaćeno učešće u procesu investiranja; $\left({ }^{*}\right)$ davanje značenja pokrećući filozofsku poruku i transcendenciju; $(*)$ pravilno korišćenje i upravljanje; $(*)$ postizanje socijalnih i kulturnih ciljeva; $(*)$ sposobnost planiranja transformacije / revitalizacije postojećih arhitektonskih objekata.

Istraživačka metoda je analiza navedenih komponenti na osnovu izvora iz literature i primera arhitektonskih objekata ili urbanih kompleksa.

Razmatranja vode do teze: Lepota u arhitekturi je stanje harmonije estetskih i upotrebnih vrednosti oblikovanog prostora u odnosima kreativnog odgovora na široko shvaćene uslove lokalnog, prirodnog, socijalno-kulturnog i izgradjenog okruženja.

KLJUČNE REČI: LEPOTA U ARHITEKTURI, KRITERIJUMI LEPOTE U ARHITEKTURI, HARMONIJA ARHITEKTURE I OKRUŽENJA, FILOZOFIJA ARHITEKTURE, ESTETIKA ARHITEKTURE

\section{ARHITEKTURA KAO INSTRUMENT ESTETSKE I POLITICKE MISLI Thomas SYMEONIDIS}

Uprkos uobičajenom pristupu arhitekture u smislu zamisli, dizajna i izgradnje izgradjenog okruženja, u ovom radu ističemo da se arhitektura može koristiti kao instrument estetske i političke misli. Zbog toga se oslanjamo na definicije arhitekture ističući ili njene aspekte principa (arché) ili konstrukcije ili njen relacijski karakter. S tim u vezi, arhitektura će se koristiti kao sredstvo za pitanja konceptualizacije i promišljanja na preseku dve ključne tačke političke teorije - jednakosti i pravde. 
Glavna hipoteza je da se u savremenom estetskom režimu misao o estetici ne može razlikovati od politike čime se podržavaju glavni aspekti relevantnih doprinosa Žaka Ransiera (Jacques Rancière). U ovoj analizi počinje se sa prikazivanjem srodnosti izmedju političke i estetske misli, a zatim se razradjuju aspekti arhitekture kao skale, tipa, oblika, dijagrama, istorije i hijerarhije kako bi se prikazalo funkcionisanje arhitekture kao instrumenta misli. U tom cilju prikazana je čvrsta shema i definicija misli u savremenoj filozofiji.

Uspostavljanjem analogija izmedju procesa misli i procesa arhitekture, na kraju će se pokazati da se arhitektura može koristiti na obrnuti način tako da se istaknu pitanja estetske i političke teorije i prakse.

KLJUČNE REČI: ESTETIKA, ARHITEKTURA, DIJAGRAM, ŽAK RANSIER, POLITIČKA TEORIJA, ODNOS, MISAO

\section{DODATA VREDNOST REGENERATIVNE ARHITEKTURE I FILOZOFIJE SAVREMENE ESTETIKE}

\section{Andrea Wheeler}

Regenerativna arhitektura teži da pozitivno utiče na okruženje. Njen cilj je da proizvede objekte koji umanjuju degenerativne posledice ljudske aktivnosti, a koje pozitivno utiču na životnu sredinu. Da bi se dodala vrednost, u dimenzijama kao što je lepota, uključena u projektne pristupe regenerativne arhitekture i, na primer, Living Building Challenge, gde se biofilija i biomimetika postavljaju kao aspiracija, s druge strane, postavljaju se neka osnovna pitanja vezana za načine razmišljanja koji predstavljaju osnovu regenerativne arhitekture i discipline arhitekture. Instrumenti projektovanja sugerišu da se ,više od karaktera“ može odrediti, čak i izmeriti u svim kategorijama, ali aspiracije takodje zahtevaju radikalne promene načina na koji posmatramo i razumemo život ljudi. Razumevanje estetike i primat senzorne povezanosti sa okolinom pitanja su koja nisu puno priznata u filozofiji regenerativnog dizajna izvan sugestije biofilije. Ovaj rad se bavi istraživanjem osnova estetike okoline: pričama, mitovima, snovima i značajem kreativne zamisli u shvatanju i ponovnom vrednovanju načina na koji posmatramo i razumemo ljudske živote i naš odnos prema izgradjenoj i prirodnoj sredini.

KLJUČNE REČI: ODRŽIVO, REGENERATIVNO, INANA, BOGINJA, ESTETIKA, FILOZOFIJA, ARHITEKTURA, TEORIJA, DIZAJN, FEMINIZAM

OD POZNATOG DO MISTERIOZNOG.

ESTETIKA ATMOSFERA U DOMAĆIM PROSTORIMA

\section{Elisabetta Di Stefano}

Pojam „poznatog“ je nedavno postao ključan u debati koja je pokrenuta u „Svakodnevnoj estetici“ (Everyday Aesthetics). U ovom eseju ću istražiti ovaj koncept u teorijama Arto Hapala (Arto Haapala) i Juriko Saito (Yuriko Saito), a zatim ću ispitati pojam poznatog - i nekih antonimskih pojmova (tj. čudno, misteriozno, strano) - prihvatajući fenomenološki pristup. Pozivajući se na teoriju atmosfera nemačkog fenomenologa Gernota Bohmea (Gernot Böhme), moj rad poredi pojam staklene kuće, o kom je bilo reči u modernističkoj teoriji, i pojam kuće školjke, koji su iz različitih perspektiva posmatrali Valter Benjamin (Walter Benjamin), Gaston Baselar (Gaston Bachelard) i Juhani Palasma (Juhani Pallasmaa). Na kraju ću povući paralelu sa pojmom čudnog koje se možda pretvara u ideju misterioznog ili stranog, na primer kada se providnost stakla koristi kao alat za kontrolu ili kada je ono ugrađeno u digitalne ekrane hipertehnoloških domova.

KLJUČNE REČI: ESTETIKA ARHITEKTURE, SVAKODNEVNA ESTETIKA, ČUDNO / POZNATO, STAKLENA KUĆA, HIPERTEHNOLOŠKE KUĆE, MODERNIZAM 